\title{
A RECEPÇÃO DA OBRA DE GILBERTO FREYRE NO RIO GRANDE DO SUL*
}

Letícia Nedel

Gilberto Freyre já era, além de um sociólogo conhecido, um viajante experimentado quando foi conhecer o Rio Grande do Sul. Quase dez anos depois de deflagrada a Revolução que o teria conduzido ao exílio voluntário em Lisboa, Freyre fez duas viagens consecutivas ao estado, em 1939 e em 1940. Na primeira, a convite do interventor Cordeiro de Farias, chegou com José Lins do Rego. Visitaram jornais, cafés, a Livraria do Globo, as instituições eruditas da capital, depois seguiram de trem pelo interior, acompanhados do escritor Gilberto Vianna Moog e do historiador Dante de Laytano. Era o tempo da Campanha de Nacionalização do Ensino, e os cicerones tinham sido expressamente designados pelo Secretário de Educação e Saúde Pública para mostrarem aos hóspedes os atrativos da Serra, das Missões, da Campanha e do Litoral. "Naturalmente eles terminaram por nos mostrar o Rio Grande. E não nós a eles", foi o comentário de Laytano (1986:35), então chefe de gabinete do secretário J.P. Coelho de Souza, a propósito da viagem.

A segunda estada, desta vez acompanhada de Gastão Cruls, teve objetivos acadêmicos mais imediatos. Como convidado de honra do prefeito José Loureiro da Silva, Freyre apresentou a tese "Sugestões para o Estudo Histórico e Social do Sobrado no Rio Grande do Sul". Proferiu uma conferência que se tornaria célebre, intitulada "Continente e Ilha", no III Congresso de História e Geografia, realizado pelo Instituto Histórico e Geográfico local (IHGRS), em alusão ao bicentenário da fundação de Porto Alegre. Vale assinalar de passagem que, no encerramento do mesmo congresso, Freyre assistiu à entrega do diploma de sócio benemérito do Instituto a Getúlio Vargas. Na ocasião, os eruditos manifestaram publicamente o apoio à decisão sobre os "destinos nacionalistas" do país, tomada em face da antevisão de um "revolucionismo alarmante" e da proliferação de "ideologias contrabandeadas", que estariam "ameaçando a tranqüilidade pública" do Brasil. ${ }^{1}$ 
Depois dessas duas visitas, vieram outras (até 1969, data da última), preenchidas, nos intervalos, por prefácios e recepções ocasionais oferecidas no solar de Apipucos a autodenominados discípulos e admiradores do sul. Mas de todos os encontros, os dois primeiros é que, talvez pelo caráter inaugural e de mútuo reconhecimento que tiveram, acabaram se tornando lendários entre os membros do chamado "grupo da Livraria do Globo" com quem Freyre travou contatos na ocasião. Daquelas visitas ficaram amizades, anedotas e um repertório escrito (menos copioso, é verdade, do que o anedotário), no qual o recifense, conhecido por decifrar as diferentes formas de inclusão das regiões brasileiras na "civilização lusitana erguida nos trópicos", ocupava-se da menos tropical delas e da mais tardiamente incorporada ao império colonial português. Uma área conhecida, para desgosto de seus representantes, como o limite daquela civilização², o estado mais "estrangeiro" do Brasil; aquele que em 1967, em um artigo de Vianna Moog, ainda era descrito como um desconhecido dos brasileiros. ${ }^{3}$ E talvez tenha sido esta a maior revelação trazida a Freyre pelos gaúchos que conheceu: a decisão de se fazerem representar, a qualquer preço, dentro de limites luso-brasileiros.

A eles, o cientista ofereceu uma espécie de saída metodológica em Continente e Ilha. Na conferência, o autor procurou dar conta do que chamou de "heterodoxia cronológica" (e, por que não dizer, étnica) do Rio Grande, descrevendo a forma particular pela qual o Império Colonial Português teria sabido estender sua influência de norte a sul do continente americano: no norte, pelos primeiros portugueses; no sul, pelos luso-brasileiros e açorianos. A idéia-mestra do trabalho era a de que, ao lado do sentido continental do esforço colonizador na América, a "civilização atlântica" teria se forjado não só da forma comum - baseada na expansão de um centro dispersor para as áreas periféricas - mas através de "ilhas sociológicas" "de coagulação da energia lusitana em [...] áreas economicamente estratégicas, que depois se acentuariam em regiões mais amplamente culturais" (Freyre 1943:18; grifado no original). A sustentação da unidade de um império continental e submetido a precárias condições de povoamento seria devida, então, a terem os luso-brasileiros unido "o sentido de arquipélago [...] ao de ilha. O sentido de ilha ao de continente" (Freyre 1943:21); "um sentido completando, retificando, corrigindo o outro". (Freyre 1943:24). Na ponta meridional do Brasil, a colonização açoriana, feita a partir de casais, seria um fator de estabilização da conquista portuguesa sobre uma área conflituosa (Freyre 1943:25-26). A densidade adquirida por essa herança ilhoa, suficiente para deter as influências castelhanas, serviria à assimilação de futuras correntes migratórias que, uma vez aculturadas, prestariam serviço ao adensamento do "espírito nacional". 
Mais tarde, esses postulados seriam retomados por autores gaúchos interessados em lançar as bases de uma história pacífica e urbana do Rio Grande do Sul, distanciada das teorias da fronteira predominantes desde Julio de Castilhos até o final do Estado Novo. Diferente das anteriores, perigosamente parecidas com as das repúblicas do Prata, já que feitas de caudilhos e revoluções, essa história de "densidade folclórica" (a expressão é de Freyre) abrangia temas como a arquitetura, religiosidade e outros elementos sensíveis da contribuição cotidiana de "troncos originais" e das chamadas etnias novas para o "caráter regional" sul-brasileiro.

Como dado significativo, se é no auge do Estado Novo que o Rio Grande do Sul se desenha aos olhos de Freyre como uma área cultural passível de ser estudada, o modo como os autores locais lançam mão desse olhar "estrangeiro" para retratarem a si próprios só vai se fazer explícito nos anos imediatamente posteriores à deposição de Getúlio Vargas. É no contexto do pós II Guerra, quando o revisionismo toma conta da produção escrita sobre as origens históricas e culturais do estado, que referências literais a Freyre, e não mais aquelas difundidas anonimamente na vulgata da "fábula das três raças", vão se fazer presentes na historiografia.

O presente artigo pretende explorar o sentido estratégico desse alinhamento tardiamente declarado com as opções analíticas do autor de Casa Grande e Senzala. Embora as apropriações variassem de autor para autor, e não obstante terem sido altamente controversas, gerando enfrentamentos e desafetos entre os sócios do Instituto Histórico e Geográfico do Rio Grandeestando em jogo nos embates as atuações políticas pregressas, bem como as respectivas especialidades e posições ocupadas nas escalas de prestígio e redes de reconhecimento local - é possível encontrar na lógica cruzada pela qual esses autores articulam sua identidade profissional às propriedades de origem do território um eixo de unificação de interesses, para além de discordâncias pontuais.

Em um contexto marcado pelas novas práticas rituais e comerciais de base identitária introduzidas com a voga tradicionalista (Oliven 1992) e pelo alargamento do aparato burocrático de gestão cultural no estado, a revisão das interpretações canônicas sobre a origem e a cultura regionais impõese à comunidade intelectual já consagrada como um desafio que articula dois níveis de alteridade. Internamente, ela responde ao acirramento da competição com novos mediadores alçados aos postos públicos de gestão da memória e, no que diz respeito às relações com velhos pares conhecidos, converte a antiga missão política de projeção do Rio Grande ao poder central em uma missão de reabilitação externa da imagem cultural do estado e de seus representantes. 
A análise irá deter-se então sobre os dois aspectos menos visíveis desse processo, à época conhecido como "o advento do gauchismo": primeiro, a especificidade do momento em que as interpretações de Freyre sobre o ethos nacional passam a servir de modelo para a compreensão do passado e da cultura sul-rio-grandenses; segundo, as escolhas e os constrangimentos implícitos à adoção de postulados culturalistas por membros da comunidade intelectual gaúcha.

De fato, essas questões não mereceram até agora uma análise específica, a despeito de se fazerem candentes na documentação bibliográfica da década de 50. Os estudos de referência sobre a historiografia sulina ainda ignoram quaisquer tentativas de inovação conceitual ou temática levadas a efeito no período indicado, privilegiando uma cronologia que se estende, sem qualquer ponto de inflexão, dos anos 20 aos 70 (Gutfreind 1989, 1995; Almeida 1983; Torres 1997). Ressaltam-se, nessas análises, o interesse quase exclusivo pela hagiografia política, o "ecletismo teórico" de intelectuais polígrafos e autodidatas, a fusão e o aproveitamento dos determinismos de Ratzel e de Spencer com a famosa tríade taineana baseada no meio-raçamomento. No entanto, passa em branco o impacto das interlocuções travadas com intelectuais de outros estados e de diferentes áreas do conhecimento sobre a pesquisa por eles produzida.

Curiosamente, o desejo manifesto de atualização profissional, entendido como meio de superar o isolamento dos debates paroquiais, atravessa de ponta a ponta os projetos intelectuais sustentados por autores gaúchos dos anos 1940-1960. Tais projetos foram abordados em dois momentos de minha trajetória acadêmica. Por isso, antes de avançar no assunto propriamente dito, parece interessante recuperar um pouco do itinerário de pesquisa que conduziu ao tema do texto. A oportunidade vale para sistematizar alguns pontos que se encontram dispersos nos estudos anteriores, retirar dali o essencial e com ele fazer uma espécie de balanço da participação de Freyre em uma controvérsia durável na historiografia local: refiro-me às formas de inclusão do Rio Grande no arcabouço cultural brasileiro.

Por diferentes entradas, enfoquei o papel mediador desempenhado pelo proselitismo regionalista na socialização profissional dos intelectuais, na definição de políticas públicas de cultura e nas formas eruditas de elucidação da formação sul-rio-grandense, criadas ao longo da primeira metade do século XX. Em um primeiro caso, examinando a reorganização de um 
museu fundado em Porto Alegre, em 1903, a partir do referencial das ciências naturais e que, sob o comando de Dante de Laytano, um dos maiores divulgadores de Freyre no estado, passou a se dedicar com exclusividade à história e ao folclore ditos regionais nos anos 50 (Nedel 1999). No segundo trabalho (Nedel 2005), analisando as disputas, as alianças táticas e os empréstimos conceituais entre representantes locais de um movimento intelectual coordenado a partir do centro do país - o folclorismo (Vilhena 1997) - e destes com os líderes fundadores de um movimento de massas expandido dentro e fora do Rio Grande do Sul entre as décadas de 1940 e 1960 - o tradicionalismo (Oliven 1992).

Nos dois estudos, as tensões internas ao discurso de exaltação do Rio Grande do Sul foram situadas, como é recomendável, no contexto mais amplo da circulação de parâmetros de representação da nacionalidade e no curso evolutivo do pensamento social brasileiro de uma forma geral. A construção dos objetos de análise tratava de considerar, além da já mencionada interdependência entre as mitologias regionais e nacional, o fato de que, no bojo mesmo da disputa entre as elites culturais dos estados pela formulação de bens sancionados como "autenticamente brasileiros", forjavam-se identidades sociais e desenrolavam-se lutas classificatórias que serviriam, no percurso, para delimitar fronteiras entre os domínios da arte, da ciência e do patrimônio.

Esses pressupostos servem agora para precisar a forma como se pretende interpretar a inserção de Gilberto Freyre na vida intelectual sul-riograndense. Sua significação será avaliada em uma perspectiva relacional, que inclui os processos de atualização e readequação das narrativas regionais a modelos hegemônicos de representação da cultura brasileira. Neste terreno, não é difícil reconhecer o sucesso alcançado por ele e pelos representantes nordestinos da "segunda geração modernista", como José Lins do Rego, Raquel de Queiroz, Graciliano Ramos e Jorge Amado. Nos anos 30 e 40, esses autores não apenas contribuíram para especificar um padrão identitário propriamente nordestino - referente a uma região até então classificada genericamente como "Norte" — mas tornaram-se enunciadores privilegiados dos mitos fundacionais do Brasil. À mesma época (e talvez hoje não seja muito diferente), o Rio Grande do Sul era noticiado por um jornal do Recife como o estado "de onde saiu o regionalismo mais acirrado que se tem notícia na literatura nacional"4.

Tendo essa desproporção em vista, a repercussão da obra de Freyre no estado parece inseparável de duas problemáticas. Primeira, a da negociação das identidades sociais e territoriais dos porta-vozes da identidade sulina, em suas relações de concorrência, com outros porta-vozes interessados na 
consagração nacional das interpretações de suas respectivas comunidades de origem. Segunda, a dos processos de ressemantização do regionalismo categoria que acompanha a emergência dos intelectuais enquanto grupo específico dentro das elites dirigentes, e que se constituiu em uma espécie de filtro através do qual os pais tutelares da Literatura e da História no Rio Grande do Sul orientaram suas relações com a política, com o território e com a atividade intelectual.

Começo pelo primeiro aspecto do problema, expondo em linhas gerais o aparato conceitual operado na compreensão do fenômeno regional e suas derivações em "ismo". A seguir, passo ao processo de gestação de saberes ancestrais no Brasil dos anos 20, procurando explorar as novas conexões entre regionalismo e modernismo fabricadas na conjuntura política dos anos 30 e do Estado Novo. Ao final, examino as tensões que cercaram a participação um tanto involuntária de Gilberto Freyre na voga de aproximação dos intelectuais sul-rio-grandenses dos anos $50 \mathrm{com}$ o folclore e a cultura popular.

\section{Nação e região}

A idéia de Região, embora diga respeito ao espaço, não se reduz a uma nominação geográfica. Ela remete a uma hierarquia de valores por meio dos quais se definem diferentes graus de inclusão em uma suposta unidade cultural territorialmente circunscrita. Trata-se, portanto, de uma categoria classificatória ordinária que, conforme Pierre Bourdieu, inscreve-se em uma arena de lutas pela definição de "propriedades e sinais ligados à origem, correlatos a determinados lugares de origem" (Bourdieu 1989:113).

Historicamente, o vínculo regional impõe-se como derivação do processo de construção dos estados nacionais. Compreendida como um princípio unificador de consciências - e, segundo a bem conhecida formulação de Benedict Anderson (1989), enquanto uma "comunidade imaginada" a nação precisa ser materializada em imagens mediadoras. Na medida em que cria uma homogeneidade nova sobre espaços heterogêneos, esse novo padrão de organização social traz também o desafio de gerir suas alteridades internas. Assim, o discurso de exaltação patriótica reserva um lugar determinado para a evocação das diferenças regionais, que colaboram para ratificar a própria especificidade da nação, ao reverter em "cultural" a desigualdade política que subsiste entre os pólos.

Como ressalta Anne-Marie Thiesse, o discurso patriótico regionalista prevê, pelo recurso à paisagem e aos elementos compreendidos como "folclóricos", mais do que o controle sobre um secessionismo iminente e 
ameaçador, a construção de um consenso social e político que permita falar da diferença sem valor adversativo (Thiesse 1997:7). ${ }^{5}$ Para tanto, o discurso nacionalista apresenta as relações entre as duas esferas de pertencimento como perenes, reconhecendo a região como um elo primário de afirmação do caráter consentido - e, portanto, legitimado - da unidade maior em que se insere. Ao se distinguir das demais unidades pelo recurso a quesitos homólogos àqueles presentes no check list nacional, o espaço regional é representado de forma a facilitar a reversibilidade entre os dois códigos de classificação de origem (Thiesse 1999).

A análise dessas escalas de pertencimento deve admitir então que nem sempre as culturas definidas sobre bases territoriais tiveram um caráter evidente. Antes disso, elas resultam de um intenso trabalho de formalização dos ingredientes nos quais se ancora, sob o signo da "autenticidade", a adesão cívica dos habitantes. É metodologicamente recomendável, neste sentido, que seja considerado o desenvolvimento de uma variedade de competências e saberes que funcionam como instâncias disciplinares da memória coletiva. Esse processo diz respeito à especialização e à diversificação progressiva de atividades culturais, encenadas em mercados a princípio incipientes e localmente circunscritos, em vias de integração. Vale dizer que, pela sua própria natureza, o regional descrito pelas ciências e pelas artes só pode ser compreendido em sua integralidade quando situado no quadro federativo das práticas de sociabilidade, circulação e consagração de títulos e autores, com seus foros de enunciação, redes de reconhecimento e lugares de convergência. Os parágrafos seguintes destinam-se a uma apresentação necessariamente sumária desse processo de integração cultural no Brasil para que se aponte, a seguir, a posição ocupada pela produção escrita do Rio Grande do Sul no movimento mais amplo de redescoberta do Brasil, iniciado nos anos 20.

\section{Regionalismo, modernismo e centralização cultural}

O conjunto de paisagens oferecido pelo interior de um país ainda largamente desconhecido de si mesmo e sua contraposição à natureza exuberante da corte litorânea são aspectos que a didática naturalista na virada do século retomou do Romantismo e, dentro dela, em uma das obras fundadoras de nossa tradição sociológica, que exerceu especial influência para o devir das concepções de Brasil. No verdadeiro monumento republicano que é a obra Os Sertões, Euclides da Cunha reforçava os argumentos lançados em torno da superioridade do mestiço, realçando-a por um jogo de antíteses 
A RECEPÇÃO DA OBRA DE GILBERTO FREYRE NO RIO GRANDE DO SUL

concentradas nas qualidades "próprias" a dois tipos regionais de vaqueiros: o gaúcho e o sertanejo. Todas elas serviam para enfatizar o caráter "forte, resignado e prático" do vaqueiro do Norte, o jagunço — "Hércules Quasímodo" - obra de um meio feito de austeridade e privações que era contrastado com a vida desimpedida e com a personalidade sobranceira do campeiro sul-rio-grandense:

O vaqueiro do Norte é a sua antítese. Na postura, no gesto, na palavra, na índole e nos hábitos não há equipará-los. O primeiro, filho dos plainos sem fins, afeito às correrias fáceis nos pampas e adaptado a uma natureza carinhosa que o encanta, tem certo, feição mais cavalheirosa e atraente. A luta pela vida não lhe assume o caráter selvagem da dos sertões do Norte. [...] Desperta para a vida amando a natureza deslumbrante que o aviventa; e passa pela vida, aventureiro, jovial, diserto, valente e fanfarrão, despreocupado, tendo o trabalho como uma diversão. [...] As suas vestes são um traje de festa, ante a vestimenta rústica do vaqueiro (Cunha 1995 [1902]:82-83).

No período de ruptura seguinte à Primeira Guerra Mundial, marcado pela crítica às realizações da República e pelo julgamento do passado colonial, o apelo dos intelectuais em favor da renovação estética e do comprometimento da arte com a criação de uma cultura genuinamente brasileira cultura tida por Alberto Torres, em 1914, como "inexistente" (Garcia Jr. 1993) vai retomar o mapa etnográfico retratado pela geração de 1870 para conferir a ele novos contornos. No esteio da efervescência modernista - que, em um primeiro momento, visava equiparar as artes plásticas e a literatura do país às experiências internacionais de vanguarda — segue-se a adoção de uma perspectiva nacionalista de enfrentamento do problema da criação cultural no Brasil. É assim que, na segunda fase dos modernismos, o ataque ao "passadismo" cede lugar à questão da superação do "mimetismo". Como disse Mário de Andrade, a essa altura já não interessa mais a arte pura, "o que vale mesmo é arte interessada, arte agindo como remédio, diretriz o que diabo seja" (Moraes 2000:392) .

A homologia entre os repertórios identitários nacionais, referida no estudo de Anne-Marie Thiesse (1999), pode ser revista em escala inter-regional na acorrida de intelectuais pela decifração dos atributos que compõem o Brasil. As alteridades internas ao país são, desde aí, subdivididas em novas categorias de ligação entre povo e território que especificam, e por vezes se cruzam, com a mais antiga e abrangente oposição interior x litoral, dominante em Os Sertões. Neste contexto, as noções de regionalismo e modernismo impõem-se no centro do sistema de criação literária, manejadas pela atuação 
de intelectuais agrupados em "rodas" (era o termo que se usava) ramificadas pelo interior e pelo exterior de suas respectivas "províncias" (outro termo recorrente entre os escritores da época), todos em luta para fazer dos valores da terra itens legítimos de exportação da cultura brasileira.

A partida à padronização de caracteres relativos ao Rio Grande do Sul participa desse movimento mais amplo de intercâmbio e desenvolvimento das atividades ligadas à escrita. Internamente, ela tem como marcos inaugurais a crise da economia pecuária - da qual deriva o predomínio do acento campeiro na literatura - e a derrocada política da oligarquia liberal da fronteira sul e oeste do estado, consumada com a derrota federalista de 1895. À medida que a elite republicana consolida sua posição de comando à frente da Presidência do Estado, os valores e os atributos de honra "gauchescos" caros à elite política liberal - masculinidade, vocação guerreira, respeito aos princípios federativos - vão sendo reapropriados sob um viés moralizador baseado no legado político castilhista (Pinto 1986; Boeira 1980). Simultaneamente, o conjunto das atividades, dos atores e das iniciativas editoriais desloca-se progressivamente dos pólos charqueador e portuário do sul - Pelotas e Rio Grande - para Porto Alegre. Reproduz-se, assim, a concentração do mercado cultural local sobre a capital do estado, fato verificável também em outras regiões do país.

No Brasil, como se sabe, os ambientes mais valorizados de circulação intelectual concentravam-se em salões, livrarias e cafés do Sudeste. Para lá se dirigiam os autores aptos a ingressar no circuito de realização das ambições culturais mais vocacionadas. Na capital do país - sede das primeiras instituições representativas dessas elites - ficavam a Academia Brasileira de Letras, a Biblioteca Nacional, a Escola Nacional de Belas Artes. Em São Paulo, base do liberalismo oligárquico vitorioso com a implantação da República, desenvolvia-se o mecenato cultural que, amparando as experiências de vanguarda ensaiadas pelos modernistas, tentaria equiparar a projeção cultural do estado à sua pujança econômica. ${ }^{7}$

De fato, a agitação modernista marca o momento em que se generaliza entre as elites culturais brasileiras a tendência de recusa ao cosmopolitismo intelectual e de compromisso com os destinos da pátria. Mas, como assinalaram Garcia Jr. (1993) e Muniz de Alburquerque Jr. (2001), a despeito do clamor nacionalista, essa movimentação em favor da fundação simbólica da nacionalidade só revela toda a sua significação quando reportada ao sentimento, dominante entre os escritores, de desterro em solo próprio e de pertencimento ao universo intelectual francês. É na crise de uma sensibilidade belle époque revelada, afinal, tributária do passado colonial - e em meio à grita geral de renovação da agenda política — que aparece em 
A RECEPÇÃO DA OBRA DE GILBERTO FREYRE NO RIO GRANDE DO SUL

diferentes estados do país um discurso autoctonista vigoroso, que desarma o olhar naturalista até então predominante, excessivamente atento ao meio e à raça, para realçar, a partir daí, fatores históricos e culturais de germinação nacional.

Essa passagem do universalismo biológico ao terreno das culturas locais é repleta de ambigüidades, e se constitui no foco de discordâncias e recusas entre as diversas correntes identificadas como modernistas. ${ }^{8} \mathrm{Em}$ alguns modelos tidos por "conservadores", como o "verde-amarelo", a "gauchesca" sul-rio-grandense e o "modernismo tradicionalista" do Recife, impera um extremado senso de exaltação do passado e da "província". Já na aproximação de Mário de Andrade com as tradições populares, é a projeção da unidade nacional que fala mais alto. Para ele, o "regionalismo" adquire, no mais das vezes, o sentido pejorativo de limitação criativa somada ao particularismo político.

Ao passo que Mário manifesta sua inconformidade com o passadismo dos verdes-amarelos, identificando-os com o regionalismo tout court, os representantes desta tendência, como Menotti Del Pichia, Plínio Salgado e Cassiano Ricardo, definem o rumo de suas criações em uma direção similar àquela tomada pelas letras no Rio Grande do Sul. Eles, como os gaúchos, ocupam-se da fronteira, realçando em causa própria o papel desbravador dos heróis bandeirantes e o legado integrador dos próceres conquistadores do território. ${ }^{9}$

No que diz respeito ao Rio Grande, a produção escrita como um todo explora a posição limítrofe da campanha. Os historiadores, particularmente, fazem do gaúcho o sentinela da nacionalidade. Especializam-se em reivindicar para ele uma filiação luso-brasileira, distinguindo-o do homônimo platino (o gaucho malo), negando a existência de caudilhos no estado e vinculando o herói civilizador à progênie de tropeiros paulistas e lagunistas, ou às elites militares do Império. Ali, a fundação do representante local do IHGB, assim como a escolha de realçar a reconhecida participação gaúcha na história militar do Brasil, revelava uma estratégia específica de enfrentamento da concorrência com outros estados, que também vinham tratando, por vias próprias, de ocupar espaços na epopéia nacional. Definitivamente fundado, depois de várias tentativas ${ }^{10}$, às vésperas do centenário da independência, o Instituto Histórico aparece com a missão explícita de integrar o Rio Grande ao calendário cívico da nação, preparando a comemoração do centenário farroupilha e arquivando as teses "separatistas", predominantes ao tempo de Julio de Castilhos. ${ }^{11}$

Na ficção, a essa altura a prosa gauchesca vivia, segundo Guilhermino César, o segundo decênio de sua "idade de ouro". Depois do chamado "re- 
gionalismo naturalista" que teve em Alcides Maya o maior e mais polêmico representante, um novo surto iniciado com No Galpão, de Darcy Azambuja, lançado em 1925, teve, de acordo com o autor, o auxílio do gérmen nacionalista do Modernismo, mas do ponto de vista temático trouxe pouca novidade "[...] apenas retomou os caminhos de uma tradição" (César 1994:39). ${ }^{12}$

De fato, o cânone regionalista concentrou sobre si parcela significativa da prosa de ficção produzida no estado entre a década de 10 e os anos 50, e teve no conto, até os anos 30, a sua expressão preferencial, dando lugar, em seguida, ao romance. ${ }^{13} \mathrm{~A}$ preponderância desse estilo e, principalmente, o teor ufanista assumido pela escrita dos anos seguintes à pacificação política entre libertadores e republicanos ${ }^{14}$ não escaparam nem aos intelectuais do centro do país, nem aos da capital do estado. Em um artigo intitulado Narcisismo Gaúcho, publicado na volta da segunda viagem a Porto Alegre, Freyre assinalava com ar de condescendência o hábito do rio-grandense "de se contemplar com certo gosto e orgulho nas águas de suas lagoas" (Freyre 1940b:14). Dez anos antes, em 1930, em Separatismo Político e Regionalismo Literário $^{15}$, João Pinto da Silva, um dos primeiros e mais respeitados críticos do estado, já observava que

De todas as circunscrições do Brasil, é provavelmente o Rio Grande aquela cuja vida literária acusa mais nítidos pendores de diversificação das tonalidades dominantes no resto do país. Quero dizer que o regionalismo é aqui mais intenso do que nos outros Estados [...] Há nessa atitude um pouco de narcisismo. No caso, porém, o narcisismo tem outro nome: é exageração patriótica [...] (apud Chaves 1979:80).

Dois anos antes de Pinto da Silva, o consenso alcançado pela singularidade autoproclamada do Rio Grande do Sul permitia que Mario de Andrade exclamasse, e não sem uma ponta de malícia, ao amigo Rui Cirne Lima, "Meu Deus, como vocês aí no Rio Grande do Sul são parecidos uns com os outros! [...] são todos de uma unidade estupefaciente. Vocês de fato formam a única escola que a literatura brasileira moderna formou. Escola no amplo, mas total espírito do termo"16.

Na verdade, quando Mario de Andrade expressou essa opinião, o assinalar das excentricidades políticas e culturais do Rio Grande já atravessava duas décadas, remontando às críticas vindas de intelectuais antipositivistas, como Sílvio Romero e Capistrano de Abreu, e à implantação da ditadura que, por trinta anos, governou os gaúchos. ${ }^{17} \mathrm{~A}$ explicação para isso costumava ser buscada na geopolítica, molde do gênio de "um povo" criado em condições "anômalas" de desenvolvimento nacional. Tais condições seriam dadas, de 
saída, pelo posicionamento à esquerda da linha demarcatória de Tordesilhas, pela contigüidade da paisagem pampeana, pela dificuldade de comunicações estáveis com o restante do país e, de modo geral, pela complexidade de uma história desenrolada sobre o espaço movediço da fronteira.

Enquanto no Rio Grande do Sul é a fronteira que exerce sua força sobre a imaginação dos prosadores, no Recife, os "modernistas tradicionalistas" (Ascenso Ferreira, Odilon Nestor e Gilberto Freyre) fincam no passado colonial o núcleo civilizador do Nordeste, entendido como célula originária do Brasil. Ao representar uma região economicamente mais atrasada e politicamente alijada do Executivo central, o regionalismo pernambucano proposto por Gilberto Freyre posicionava-se contra o "mau cosmopolitismo e o falso modernismo" das elites brasileiras, particularmente as do centro do país, denunciando seu caráter "predatório" em relação aos "mais tradicionais" costumes populares e regionais brasileiros. No "Manifesto Regionalista" de $1926^{18}$, os elementos mais autênticos — os mocambos, a miscigenação apóiam-se em tudo o que para a geração de 1870 confirmava a precariedade civilizacional do país. Sua ênfase recaía, desta forma, na reabilitação dos padrões culturais próprios à sociedade agrária e patriarcal ao tempo dos engenhos, tomando o regional - e, em especial, os valores culturais do Nordeste - como unidade básica da organização nacional. Nele, o elogio nostálgico do patriarcalismo do engenho já prefigurava, sete anos antes de Casa Grande e Senzala, a apologia à mestiçagem e à cultura crioula — sendo o Nordeste "a principal bacia em que se vêm processando essas combinações, essa fusão, essa mistura de sangues e valores que ainda fervem".

Ruben George Oliven, em uma análise dos imperativos políticos do Manifesto (1992), descreve as táticas discursivas por intermédio das quais tratava-se, ali, de reverter os estigmas associados à decadência daquela área em relação ao Sudeste, e mais especificamente a São Paulo. Se não era possível competir em nível econômico, os modernistas "tradicionalistas" reclamavam o papel de protagonista para Pernambuco, no nível simbólico, como o espaço criador dos valores brasileiros. Assim, ao se defenderem de eventuais acusações de separatismo, os signatários apontavam para a precariedade do "unionismo" vigente no Brasil desde a proclamação da República. Esta, ao invés de promover a integração das diferenças - do ponto de vista político, mediante uma administração que atendesse às particularidades de cada região no que diz respeito a setores estratégicos, como o ensino e o planejamento econômico - teria apenas imposto ao país um regime estadualista, fundamentado na guerra econômica e política entre os estados e destes com a União. A permanente disputa sob um governo central "tão impotente" diante dos "desmandos dos estados grandes e ricos" quanto das 
"turbulências balcânicas de alguns pequenos em população" é que — ao contrário do regionalismo - seria a grande ameaça à unidade nacional. No mesmo texto, Gilberto Freyre opunha à "ficção necessária" chamada Brasil a "verdadeira" brasilidade: o conjunto das regiões, com suas tradições próprias e interdependentes.

Nas décadas de 30 e 40, o "retorno ao mundo rural" seria amplamente explorado pela propaganda de governo e pelo mercado editorial ascendente, enquanto o repertório brasileiro, multiplicado em microversões, acompanharia o interesse dos intelectuais por um Estado forte e intervencionista. No Brasil comandado pela revolução de outubro, a insularidade política e cultural própria da Primeira República dá lugar a um processo de integração sem precedentes na história brasileira. Neste contexto, as instâncias de produção cultural seguem concentradas sobre o centro-sul (Miceli 1979:74), enquanto no plano simbólico o Nordeste aparece como locus da autenticidade. Segundo Afrânio Garcia Júnior:

[...] o romance regionalista do Nordeste torna-se, a partir dos anos 30, o símbolo do romance tipicamente nacional. São os lugares de origem dos romancistas mais reconhecidos que se deslocam — de Rio e São Paulo para esta região, e são os assuntos tratados, o quadro da ação, a linguagem e o estilo que passam do romance urbano, do fim do séc. XIX, a um romance que retrata a decadência das plantações tradicionais (Garcia Jr. 1993:31).

O romance regionalista nordestino alimentou a concorrência entre as editoras, que tiveram nas "coleções brasilianas" o gênero de maior prestígio. ${ }^{19}$ Da concepção plural de nação que orienta aquelas coleções, é mais uma vez Gilberto Freyre - autor convidado a ser organizador da série "Documentos Brasileiros" da José Olympio - quem oferece o caso emblemático. Na verdade, a precedência afetiva da região sobre a nação é um princípio nunca abandonado por Freyre. Mesmo quando interessado em assumir a posição universalista do cientista que examina a incidência de fatores herdados e adquiridos na configuração do complexo societário brasileiro, este intérprete opera sempre em um plano de continuidade subjetiva com as tradições locais. Rodolfo Vilhena (1997:256), com base na interpretação de Ricardo Benzaquém de Araújo (1994), assinalou que mais além da influência boasiana, tantas vezes apontada no deslocamento do foco de análise da "raça" para a "cultura", a adoção da perspectiva neolamarckiana de harmonização entre contrários teria permitido a Freyre retratar a cultura brasileira como resultado de uma dinâmica estabilizadora entre "raça e cultura", "continente e ilha", "nacional e regional". 
Este esquema, como advertiu Giralda Seyferth (2000:180), contrapõe a suposta unidade interna da região, a "ilha cultural", à diversidade da nação (o continente), diversidade esta entendida como um prolongamento das dimensões do arquipélago. Neste sentido, a função lógica do nacionalismo regionalista de Freyre permite, de um lado, encontrar os elementos constitutivos da brasilidade em qualquer lugar do país, mesmo nas áreas que receberam grandes contingentes de imigrantes, como Rio Grande do Sul e São Paulo. Em compensação, instala a desigualdade em torno do gradiente de representação da nação, já que para Freyre "[...] a pluralidade é mais legítima nos limites fixados pela formação nacional herdada dos tempos coloniais, mais preservada no Nordeste - lugar onde a mistura das três tradições (portuguesa, indígena e negra) está em equilíbrio" (Seyferth 2000:182).

Para os termos desta discussão, significa dizer que se a tradição nacional fundamenta-se no passado colonial, o núcleo gerador da sociedade brasileira reside em tempos e lugares anteriores à incorporação integral do Rio Grande ao território, datada do século XIX. Não casualmente, nesta comunidade de leitores, a obra de Freyre vai figurar de maneira ambivalente: ao mesmo tempo como um documento-mestre (exemplo a ser seguido) e como prova da "nordestinização" do Brasil em detrimento de outras fisionomias regionais.

\section{O isolamento da província e a distância do Nordeste}

É no final do Estado Novo, quando a centralização política passa de solução a vilã, que os intelectuais gaúchos vão tentar reverter sua posição desfavorável na federação das letras e no repertório escatológico nacional. Ao apelar para conceitos como "aculturação", "transculturação", "assimilação", os autores tratam de gestar a própria alteridade em uma empresa coletiva e nacionalmente orientada para a institucionalização dos estudos e da proteção ao folclore dos estados, tomando-os como substrato de uma escrita revigorada pela fórmula narrativa enunciada no prefácio à primeira edição de Casa Grande \& Senzala. Na história "proustiana" de Freyre,

[...] despreza-se tudo o que a história política e militar nos oferece de empolgante por uma quase rotina de vida. [...] dentro dessa rotina é que melhor se sente o caráter de um povo. Estudando a vida doméstica dos antepassados sentimonos aos poucos nos completar: é outro meio de nos sentirmos nos outros — nos que viveram antes de nós; e em cuja vida se antecipou a nossa. É um passado que se estuda tocando em nervos; um passado que emenda com a vida de cada 
um; uma aventura de sensibilidade, não apenas um esforço de pesquisa pelos arquivos (Freyre 1992 [1933]:LXV).

Aplicado à arte literária, esse princípio serve para superar o caráter "centauriano" e "particularista" dos regionalismos anteriores. Aplicado à ciência, para refundar as bases de legitimidade do campo de produção historiográfica, recuperando a reputação heurística de uma produção monográfica excluída do processo de modernização da pesquisa social no Brasil, jogada à obsolescência e acusada de comprometimento ideológico.

Sem exclusão da legitimidade desfrutada pelos temas regionais e tampouco de alianças táticas com adversários próximos ou distantes, a comunidade rio-grandense de escritores volta-se então à reconstrução dos caracteres distintivos da região e do regionalismo como forma de reconstruir sua própria identidade profissional. Sujeita à percepção de uma atuação "periférica", ela elege como interlocutores preferenciais os supostos responsáveis por seu isolamento. Embora estes se dividissem entre os "de casa" e os "de fora", é principalmente reclamando os direitos de integração da periferia ao centro que os autores remodelam a particularidade cultural do Rio Grande e a sua própria naquele momento.

Essas elites nativas normalmente valorizavam os "olhares forasteiros" sobre sua aldeia. São fartas na documentação observações como a de Dante de Laytano a respeito da superioridade dos "exames sobre as coisas do Rio Grande feitos por não rio-grandenses", de sua capacidade de ver "a evolução dos acontecimentos colocando-se fora dos vícios do ambiente nativo" ${ }^{20}$, ou declarações como as de Moysés Vellinho, de "que [aos de fora] as perspectivas da nossa realidade se apresentam [...] com uma nitidez e um relevo que nem sempre oferecem aos de casa" (Vellinho 1957:224). A discrepância mesma entre a posição destacada em nível regional, mas subordinada na escala nacional, já desde antes incitava os autores do Rio Grande a manterem, ao longo de suas carreiras, uma dedicada intermediação com autores de outros estados. Apesar disso, o caráter quase sempre epistolar (e nem sempre assíduo) dos intercâmbios, a verticalidade em que se pautavam essas relações de troca, e o teor "doméstico" das discussões com os conterrâneos, sempre divididos pela patrulha mútua ao particularismo, confirmavam a insignificância dos debates paroquiais na agenda intelectual brasileira. Isto explica o ressentimento expresso por Dante de Laytano para com a própria condição que emblematizava, ao se qualificar diante dos amigos como um "escriba de província" (1986:38). O arcaísmo, de uso geral entre os colegas de ofício, traduzia, na prática, uma comunidade intelectual formada à distância dos principais editores, autores, instituições e livrarias do país. 
Como afirmou Laytano, "O Rio Grande do Sul era isolado do Brasil. Nós trabalhávamos falando sozinhos. Tinha aquele negócio de nordestino, pernambucano, baiano, os baianos falando 'o Brasil é baiano' e nós... nós não éramos Brasil" (Laytano 1998). Além dos editais de Moysés Vellinho na revista Província de São Pedro serem pródigos na mesma denúncia, Érico Veríssimo deixou um relato significativo a respeito da problemática circulação dos autores regionais na homenagem que fez ao conhecido colega e editor da Globo, Henrique Bertaso:

No Rio de Janeiro, o poeta-editor Augusto Frederico Schimidt lançara um livro notável, Casa Grande e Senzala, que revelava um sociólogo do porte de Gilberto Freyre. Por sua vez o livreiro José Olympio fazia-se editor e prestava inestimável serviço à literatura brasileira tornando conhecidos, além de outros, romancistas como Graciliano Ramos, Jorge Amado, José Lins do Rego, José Américo de Almeida e Raquel de Queiroz, que davam novos rumos à literatura do Brasil. [...] Mas eram escritores da 'Corte'! Apareciam na capital do país. Tinham, além de seu valor próprio indiscutível, boa imprensa. Nós estávamos na província não só geográfica, mas também — tínhamos de reconhecer — psicologicamente (Veríssimo 1973:38-39).

Em contraste com o alcance nacional e internacional conquistado pela literatura do cangaço, do açúcar e do cacau, o parco interesse comercial revelado pela gauchesca parecia confirmar a suspeita de isolamento, como informa o relato de Otavio Bertaso, filho de Henrique:

Toda vez que recebíamos um original versando sobre a história do Rio Grande do Sul ou uma biografia de seus homens ilustres, eu ficava um tanto desanimado um livro relatando as proezas dos valentes gaúchos que por séculos a fio haviam defendido as nossas fronteiras, ou dos políticos que haviam conseguido consolidar o prestígio do Rio Grande do Sul no cenário nacional despertava um interesse minguado. Para falar a verdade, um minguadíssimo interesse, que se restringia tão-somente às fronteiras do estado. [...] as tiragens [...] eram de 2 mil exemplares e em média levavam cinco anos para se esgotar quando vendidas nas livrarias (Bertaso 1993:142).

Tudo indicava que aos olhos dos consumidores de livros o gaúcho detinha um poder menor de evocação das qualidades essenciais ao brasileiro, sobretudo em comparação à figura do sertanejo. Como elemento folk, ele se prendia a uma história particular, e não raro acusada de ser culturalmente deficiente pelos próprios conterrâneos. Assim é que, tentando encaminhar nos anos 70 
uma questão que "há muito" o preocupava, Guilhermino César chegou a formular diretamente a pergunta que já naqueles tempos não queria calar:

Por que o leitor carioca, mineiro, paulista - falo grosso modo — prefere um José Lins do Rego a um Cyro Martins? [...] Denúncia social por denúncia social, ela é muito mais cortante, para dar um exemplo, em Sem Rumo (1937) do que em A Bagaceira ou Capitães de Areia, ambos editados na mesma data. [...] (César 1994:170-171).

Além da pouca - e para alguns, justificável — procura dos autores gaúchos nas livrarias, os ocupados do balanço literário do Rio Grande do Sul reclamavam de uma "resistência à aceitação do regionalismo rio-grandense" (Vellinho 1948:6), indicativa da diferença de peso e medida em uso quando se tratava de dimensionar o valor desta produção pelos críticos do centro do país. Enquanto os autores do "sul" vinham de ser apontados como "conservadores na linguagem"21, historicamente presos a estereótipos localistas, substantivamente divergentes na descrição psicológica de seus personagens, ou ainda simpáticos a estrangeirismos norte-americanos (caso da Globo e de Érico Veríssimo, acusados pela esquerda de adesão ao "American Way"), dizia-se que os escritores do Nordeste recuperaram aquilo que Euclides da Cunha vislumbrara: o Brasil profundo.

Depois do aparecimento de um regionalismo socialmente engajado, representado pelas obras de Pedro Wayne, Cyro Martins e Ivan Pedro de Martins - o que, em princípio, excluiria a hipótese do conservadorismo político como razão para o status rebaixado das letras sulinas — surgiram em resposta à questão duas hipóteses complementares. A primeira delas, sintetizada no testemunho deixado por Dante de Laytano, identificava entre os motivos o fato de que "O Rio Grande sempre foi marcado, sempre sempre. Todo mundo podia fazer regionalismo, menos Rio Grande. Então aqueles nordestinos, com aquele monte de livros, e nós não podíamos ter um!" (Laytano 1998). O mesmo argumento prevalece em Moysés Vellinho. Para ele, a confusão, pelos críticos nacionais, de um senso de "provincianismo sadio" com localismo separatista era prova da permanência do ranço centralizador sobre o panorama intelectual brasileiro. Não fosse este o caso, desafiava, " [...] como justificar que a crítica da corte nunca tenha recusado foros de brasilidade à literatura da seca, da cana-de-açúcar e do cacau, aos regionalismos do norte, em suma, não menos agarrados à terra que o do sul?" (Vellinho 1948:6).

A segunda resposta vai buscar internamente as razões para o baixo peso simbólico nacional do personagem típico dos pampas, isto é, na "es- 
cassez" de elementos folclóricos e na inexistência de condições ambientais que remeteriam a um Brasil primevo e tropical, teoricamente representado pela cultura popular do Nordeste. É o que se vê na hipótese "sociológica" acalentada por Guilhermino César:

Região periférica distante do Centro, zona de formação mais nova que o Nordeste, cujas linhas de força, no processo social, foram deitadas no espaço brasileiro desde os primeiros dias da Colonização, o Rio Grande do Sul tinha a seu desfavor, como elemento oferecido ao exercício do sentimentalismo do leitor, a ausência da seca. [...] O cambiteiro, a virar cana e bagaço de cana diante das moendas, naquele ambiente que Nabuco, usando a palavra justa, chamou de microcosmo, é um ser complexo. Tem interesse como homem sofrido e como homem produtor de... Folclore. É versátil, sabe cantar, dançar, rezar; ri; [...] Ora, o gaúcho, na solidão da Campanha [...] Produz menos "fatos" de cultura (César 1994:171).

Dentro da diversidade de elucubrações sobre a privação cultural do Rio Grande, a de Augusto Meyer também apresenta um interesse especial, por trazer à pauta uma avaliação da responsabilidade das elites sobre a produção do acervo documental popular em que deveria se basear a tradição escrita local. Meyer observava na carência de elementos folclóricos "originais" do Rio Grande do Sul uma omissão histórica, para não dizer historiográfica:

Se os fatos miúdos da vida cultural fossem registrados pelos historiadores com a meticulosidade que põem na pesquisa da grande história - guerras, migrações, dinastias, revoluções -, poderíamos dispor de um repertório de bens históricos mais ou menos completo, para facilitar-nos a tarefa de identificá-los na sobrevivência popular (Meyer 2002 [1960]:68).

Assim, todos concordavam que no Rio Grande, ao contrário dos estados do Nordeste, sobrava tradição política e "faltava cultura popular". Veladamente, chegava-se à conclusão de que o teor elitista da história praticada no IHGRS tinha contribuído para a escassez desses registros. Hegemônica depois da queda do Estado Novo, a conclusão foi compartilhada tanto por antigos defensores do regionalismo literário - casos de Dante de Laytano, Darcy Azambuja e Manoelito de Ornellas - quanto por outros autores engajados no projeto revolucionário de 1930, que naquele tempo recomendaram seu abandono. É o caso de Meyer, "um intelectual cosmopolita [...] já provado na matéria nacional (Machado de Assis), [...] que reflui ao pago para meditar sobre autores ou obras tidos como secundários, senão menores mesmo"22 (Fischer 2002). 
Na raiz dessa convergência de opiniões, reside o fato de que a tradicional fusão simbólica entre o gaúcho heróico e o agente da conquista lusitana tivesse se consolidado internamente justo no momento em que, no centro e em outras regiões do país, os estudos sobre folclore e cultura afro-brasileira passavam a ser valorizados. Enquanto a mestiçagem era revertida em elemento positivo, característico do tipo brasileiro, os historiadores do IHGRS continuavam zelando pela frondosa árvore genealógica que ligava seus heróis farroupilhas e republicanos às elites do Império. Com a frustração do sonho de gauchização do Brasil, uma parte significativa dos protagonistas da revolução de 30 notava esse descompasso. Eles observavam que nos modelos consagrados de retratação da cultura brasileira o Rio Grande do Sul não só tinha ficado de fora, como tinha investido no vazio, ao alimentar a memória oficial com as qualidades militares de um panteão político que, no decorrer dos anos, acabaria por revelar uma legitimidade duvidosa. Essa avaliação confere com a crítica de Cyro Martins, lançada como prefácio ao romance Sem rumo, de 1944:

A revolução repercutiu sem demora nas letras da província, propiciando uma rumorosa atividade, que se prolongou por quase um decênio. Mas essa atividade, devido ao espírito imediatista dominante, em geral careceu de valia [...] regionalistas desse período [...] contribu[íram] para que se prolongasse entre nós o culto das aparências, mascarando a visão fiel da verdade humana e das circunstâncias e dramas da coletividade crioula. Esse pacto com o convencional nos desviou, por mais de dez anos, da reflexão ponderada acerca dos nossos desígnios como povo. Essa insistência retórica da mentira, não raro coroada de fugazes vitórias, redundou numa quase fatalidade para a literatura gauchesca, porque a lançou no descrédito, dentro e fora do Rio Grande. ${ }^{23}$

O problema que se colocava então não era tanto o da permanência da temática regional em si, mas o das formas de trabalhá-la — ou, mais precisamente, o dos critérios de autenticidade mobilizados nesse trabalho. Concluía-se que o artificialismo desfigurador e homogeneizante dos retratos heróicos do gaúcho é que teriam diminuído o grau de representatividade da gauchesca diante das outras produções regionais. Mergulhar no passado buscando um gaúcho "visto de baixo" parecia a uma parcela dos autores um meio eficaz de recuperar tanto a dignidade do personagem-chave de suas criações, quanto a reputação intelectual dos encarregados de reerguer a produção cultural do Rio Grande. De novo é Cyro Martins, um dos mais conhecidos emissários dessa tendência na literatura, quem enfrenta a questão no mesmo ensaio "Visão crítica do regionalismo", publicado no apagar das luzes da ditadura varguista. Para este autor, a atitude a ser assumida 
em prol dessa renovação já se oferecia há tempos por Gilberto Freyre, que no prefácio à Região e tradição tinha deixado uma "norma de investigação" extensiva ao conjunto das expressões escritas da região:

Apoiemo-nos mais uma vez no autor de Casa Grande \& Senzala: "Simplicidade de expressão, simpatia humana pelos assuntos cotidianos e pelo mais próximo de todos nós - o nosso passado íntimo". Isto significa que devíamos substituir a romântica perspectiva do conjunto da história, do lendário, dos costumes e da paisagem, pelo enfoque realista, no sentido do aproveitamento crítico, com finalidade criadora, das próprias vivências e da dramática social. E para que não houvesse uma discordância entre o método e a técnica, precisávamos começar pela ampliação do material a explorar. Até bem pouco o nosso regionalismo estava limitado à campanha. E nesta, à estância. E nesta, no galpão. ${ }^{24}$

O texto do escritor ilustra uma tendência "à esquerda" de uma adesão que se manifesta de outro modo entre os pesquisadores. Há no período uma grande quantidade de ensaios de história e de folclore que se vale da tradição oral para seguir expressamente as recomendações do autor pernambucano. Com largo uso de almanaques e de vestígios do cotidiano, como manuscritos familiares e cadernos de receitas, os autores de certa forma tentavam também emendar a história até então reservada aos heróis com "a vida de cada um". Mais do que a construção política do Estado, lhes interessava recuperar o processo coletivo de gestação, pelo povo, da nação, que deveria ser retraduzida em escala local. Mesmo sem propor grandes rupturas epistemológicas com a historiografia inspirada na tríade taineana do meio-raça e momento, essa espécie de "história social" desafiava os limites estreitos da crônica política baseada na vida e na obra de mandatários do Estado. Ela reabilitava, além disso, a validade de fontes não-oficiais, até ali preteridas pelos historiadores em favor da documentação diplomática.

Segundo Dante de Laytano, a influência de Freyre sobre ele e a sua geração foi:

Toda. Todos nós sofremos a influência dele. [...] Ele foi um dos primeiros a estudar a história brasileira sob o ponto de vista social. A sociologia brasileira nasceu com Gilberto Freyre. Foi muito bonito, porque ele mostrou que deviase interpretar a história, e não só revelar datas. [Seus ensinamentos foram] Primeiro: voltarmos pros assuntos brasileiros, foi o primeiro passo. Segundo: os assuntos locais. E terceiro: só estudar a história da terra da gente. Se tem uma história da França, é da França e acabou-se. E nós, do Rio Grande? Quem é que vai estudar? (Laytano 1998). 
A lição confere com os enunciados da Aula inaugural dos cursos da Faculdade de Filosofia da Universidade do Rio Grande do Sul, proferida por Laytano em 1953, com o título "A História e suas Relações com Algumas Ciências". As ciências escolhidas foram a etnografia (representada pelo que ele chamou de "literatura etnográfica" de Sílvio Romero), a antropologia (por Oliveira Viana, na esteira de Nina Rodrigues e no prenúncio de Arthur Ramos) e a sociologia (fundada por Gilberto Freyre). Após destacar que "Toda a sociologia de Gilberto Freyre se abebera nos fundamentos históricos das nossas instituições" (:9), Laytano descreve os cinco pontos em que esse autor teria dado novos rumos ao conhecimento da cultura brasileira: “a) Renovação e impulso dos estudos dos afro-brasileiros; b) Valorização da obra de colonizador do português; c) Difusão, entre nós, de estudos notáveis de norteamericanos e ingleses [...]; d) História das cidades brasileiras tradicionais; e) Atenção e importância para os pequenos fatos sociais, os detalhes e os pormenores" (:18). O resto da conferência é todo feito de citações — referentes às formas como a sociologia e a história servem uma à outra, e ambas à valorização das culturas regionais - precedidas da justificativa, dada por Laytano, de que "Não encontraríamos em nenhum outro autor melhor definida e explicada as relações da história com a sociologia" (:21) ${ }^{25}$

A adesão a esses ensinamentos exigiu dos autores locais, além de um grande esforço de conversão "teórica", a adoção, em seus escritos, de um tom aberto a controvérsias. Neste sentido, parece significativo que antes da chegada da autodenominada historiografia crítica da década de $1980-$ defendida por autores saídos, na maioria, do ambiente universitário e especialmente dos programas de pós-graduação da USP (Almeida 1983:42) — as primeiras contraditas à presumida escravidão "branda" de uma região onde o negro teria pouca ou nenhuma relevância demográfica tenham partido exatamente das análises dos sócios do Instituto convertidos ao estudo das manifestações "populares" da cultura regional. ${ }^{26}$ Assim é que, por exemplo, Augusto Meyer manifestou na terceira edição de Prosa dos Pagos (1960), sua inconformidade com a continuidade das interpretações canônicas da história dos anos 30 .

[...] é difícil manter, na historiografia rio-grandense, os velhos preconceitos de uma homogeneidade cultural - cultural no sentido sociológico - que nunca existiu. Qualquer tentativa de interpretação de nossa história deverá levar em conta, como fator básico, o critério de aculturação. Aceitar passivamente o prejuízo da homogeneidade social ou política de um grupo rio-grandense, dentro de outro bloco luso-brasileiro, caracterizado e definido por simples idealização do autor, e conforme suas preferências, é prosseguir no cultivo de uma história 
em que tudo parece acontecer por obra e graça de uma Divina Providência Gaúcha. [...] (Meyer 2002 [1960]:40; grifos meus).

Outro dos críticos de primeira hora foi Dante de Laytano, secretário regional da Comissão Nacional de Folclore. Para ele, a relevância dos estudos sobre o contingente de afro-descendentes significou, ao lado da ênfase açoriana sobre o luso-brasileirismo rio-grandense, uma causa constantemente defendida na carreira como historiador e folclorista. Em diversos escritos ${ }^{27} \mathrm{o}$ historiador volta à carga na defesa desse objeto. Na monografia sem data de publicação, lançada pelos cadernos da Comissão Gaúcha de Folclore com o título a "A Igreja e os Orixás", a conclusão é francamente polemista:

[As] "Casas de Batuque" de Porto Alegre são uma resposta franca aos pesquisadores de superfície que negam, com desprezo, a realística presença do negro na própria História do Rio Grande do Sul. Não apenas na etonografia [sic] religiosa. Nas curiosidade[s] das práticas africanas transmitidas intactas através de gerações. [...] Os Batuques foram, no sentimento possível, refúgios espirituais da raça negra massacrada (Laytano s/d:60).

Ainda quanto a esse ponto, o estudo de Augusto Meyer sobre a história semântica da palavra gaúcho é revelador. O autor arma-o como um ataque frontal aos defensores - representados, no texto, por historiadores militares como João Borges Fortes e Jorge Sallis Goulart — de uma historiografia obsoleta, que como por inércia continuava apresentando "a estância como verdadeira escola de democracia, interpretação que não resiste ao exame da realidade econômica e social da época. Bom serviço prestaria quem se dispusesse a mostrar a inconsistência dessas antecipações de síntese histórica, por simples falta de monografias" (Meyer 2002 [1960]:44). ${ }^{28}$

Antes de Meyer, o amigo, companheiro "dos tempos heróicos" do restaurante Dona Maria e sócio do Instituto Histórico e da Comissão Gaúcha de Folclore, Athos Damasceno Ferreira, tinha feito em forma de novela o que em pesquisa se anunciava como um tema atraente. Em Moleque (de 1938), história passada no ambiente suburbano de Porto Alegre, levantara o problema da ascensão social do negro, retratando o cotidiano de um menino descendente de escravos agregado em uma casa de arrabalde. ${ }^{29}$ Em 1949, ele ingressa no Instituto Histórico e se volta em definitivo a esses estudos. "Gilberto Freyre, se não me engano, foi o primeiro autor de categoria nacional a estimular no cronista de Porto Alegre o gosto pelos flagrantes sociais profundos", recorda Guilhermino César (1994:138). E de fato, esta filiação é clara, do estilo da escrita à escolha dos temas. 
Inicialmente, Athos segue a trilha lançada em "Sugestões para o Estudo Histórico e Social do sobrado no Rio Grande do Sul". No artigo de 1945, intitulado "Sacadas e sacadinhas porto-alegrenses", o cronista de Porto Alegre esquadrinha, por dentro e por fora, das sacadas aos móveis, aquele "[...] tipo de arquitetura mais urbana que rural — o sobrado — do ponto de vista rio-grandense do Sul", conforme a sugestão deixada por Freyre no III Congresso Rio-grandense de História e Geografia. ${ }^{30}$ Em outro artigo, publicado em 1954, ressalta a diversidade social da indumentária usada na província. Ali o autor identifica um panorama "[...] muito parecido com o quadro da Bahia, do Rio, do Recife, de Minas - quadro álacre e bizarro de que, em largas pinceladas, nos dá um instantâneo tão saboroso, em 'Casa Grande e Senzala', o incomensurável Gilberto Freyre" (Ferreira 1954:96). Não o ambiente rural e militar do repisado gaúcho do século XVIII, mas a cor local da cidade do século XIX, com sua multiplicidade de costumes e personagens, é que figura no centro dessa espécie de "história social" apropriada de Freyre por Damasceno. No mencionado estudo, o autor oferece também um contraponto à vestimenta típica habitualmente retratada no Rio Grande do Sul:

Ao passo que entre os gaúchos era a indumentária masculina que brilhava, entre os negros entrados [...] como bichos, era exatamente a indumentária feminina, a vestimenta das pretas, que dava o tom, oferecendo, pela sua composição e colorido, um interesse folclórico que o traje do crioulo não oferecia, como não oferecia por seu turno o da escorrida chinoca pampeana com sua saia de chita tão vulgar quanto o vulgaríssimo calção do mísero escravo lanhado, do tempo do carimbo e do palanque (Ferreira 1954:93).

O conjunto dessas citações ilustra a introdução progressiva de uma paleta de cores culturalista na produção textual local, agora ocupada em alargar os contornos da paisagem social rio-grandense. É possível observar nas obras dos autores mais diretamente ligados aos estudos de folclore (os quais formam uma ala dissidente dentro do IHGRS), uma rotação no eixo norteador das abordagens. Estas se deslocam da história política para o trabalho com referenciais e temas que tomam o inventário cultural das regiões como ponto de partida do entendimento do Brasil. Suas tomadas de posição em favor de uma revisão "social" da história regional convocam à escrita de uma narrativa que reorganiza as relações da parte com o todo, permitindo operar sobre a antiga ambivalência fronteiriça do Rio Grande de um novo ponto de vista. Renova-se, deste modo, a validade da crítica nacionalista aos historiadores que, no início do século, sob influência do isolacionismo 
A RECEPÇÃO DA OBRA DE GILBERTO FREYRE NO RIO GRANDE DO SUL

político de Castilhos, tinham-no vinculado à órbita de influência castelhana. Como disse Laytano,

Um tratadista de história gaúcha incluiu todas as revoluções do Rio Grande num ciclo denominado de Revoluções Cisplatinas. Foi Alfredo Varella, uma cultura e um mestre. Hoje, uma nova doutrina, uma revisão mais decisiva, e uma defesa da cultura luso-brasileira, que Gilberto Freyre pôs em moda, em circulação e uso, trouxeram-nos o benefício de verificar que o Brasil é que influiu no Prata (Laytano 1983:28).

Sem comprometer as conclusões integracionistas previamente oferecidas pelas grandes narrativas nacionais, parte das representações da história mostram-se, de agora em diante, não mais na escala de um império continental controlado pela capital, mas no seio mesmo das entidades infranacionais, tomadas como instância mediadora necessária para a adesão subjetiva à nação. Para velhas intenções, novas fontes e métodos foram requisitados, respondendo às pressões do presente sobre os modos consuetudinários de leitura do passado.

Renovada pelos costumes, pela tradição oral e pelos fatos do cotidiano, a pedagogia de "defesa da cultura luso-brasileira" - tarefa sempre mencionada pelos historiadores gaúchos ao se referirem à função social de suas atividades - desvia o eixo de análise da construção do Estado e das elites políticas para as culturas "regionais populares", tidas como fontes de vitalidade da cultura brasileira. No cruzamento com a "sociologia" de Gilberto Freyre, a disciplina histórica, que até então detinha o discurso legítimo sobre a formação social do estado, toma emprestado de outras áreas uma série de objetos esquecidos e prenhes de possibilidades, como a arquitetura, a culinária, o artesanato, a indumentária e demais temas folk habitualmente limitados às páginas dos almanaques e antigos populários. Buscava-se, através deles, recompor a identidade do estado e de suas elites culturais, levando adiante a tarefa de inserir uma formação regional "desviante" nos quadros de uma cultura brasileira elaborada segundo a linha de representação plural, que havia sido fundada pelos modernismos (tradicionalistas ou não) da década de 20 e institucionalizada em plena recomposição política e administrativa dos anos 1930-1945. A oportunidade apresentava-se exatamente no momento em que as versões heróicas do regionalismo vinham perdendo legitimidade, e que a função social da pesquisa vinha sendo questionada pelas ciências emergentes, que acusavam o teor ideológico das fórmulas anteriores de elucidação da realidade brasileira. 
Recebido em 09 de junho de 2006

Aprovado em 08 de janeiro de 2007

Letícia Nedel é pesquisadora do CPDOC/ FGV. E-mail: <lnedel@fgv.br>.

\section{Notas}

* Este texto é uma versão ampliada de palestra proferida no CPDOC/ FGV em 5 de abril de 2006.

${ }^{1}$ (IHGRS 1940:CCCXXV). Estavam presentes, além dos demais sócios do Instituto, de Gilberto Freyre e de Getúlio Vargas, os interventores do Rio Grande do Sul, de São Paulo, de Santa Catarina, representantes dos interventores de Minas Gerais e Paraná, do governo de Pernambuco, o comandante da III Região Militar, secretários da Educação, Fazenda e Agricultura do RS, representantes dos secretários de Obras Públicas e Interior e o historiador Moysés Vellinho, na condição de vice-presidente do Departamento Administrativo.

${ }^{2}$ Não casualmente, José Lins do Rego, ao comentar aquela primeira viagem no prefácio à Região e tradição, retratou o estado como uma espécie de campo de provas para as teses lusitanistas do amigo: "Na nossa viagem ao Rio Grande, dezesseis anos após o Congresso Regionalista do Recife, as idéias todas de Gilberto Freyre foram se encontrando com ele na realidade. Todas elas confirmadas no contato com a gente e a terra que mais cultivavam as suas particularidades e eram, no entanto, tão irmãos dos nordestinos, dos baianos, dos mineiros, de todo o Brasil. O Rio Grande foi um campo prodigioso para o sociólogo confirmar e sentir a força da colonização portuguesa. O que ele sustentara em Casa Grande e Senzala víamos ali ao nosso contato. Casas, móveis, jeitos de falar, de andar, de sentir, de comer, de rezar e por tudo isto bem à mostra a marca lusitana, o açoriano de cara comprida de Rio Pardo vivo e bulindo ainda por toda a parte. O Brasil era o mesmo, era a grande unidade que nem meio século do estadualismo pudera corromper" (Lins do Rego 1941:20).

${ }^{3} \mathrm{O}$ artigo "O Rio Grande, esse desconhecido" integrava a reportagem intitulada "O deslumbrante Rio Grande do Sul", publicada pela revista Manchete. A referência consta do depoimento prestado por Viana Moog em Simpósio realizado na UFRGS, alusivo aos 50 anos da Revolução de 1930. Vide Moog 1983:614-627, 621.

4 "O Regionalismo no Sul". Folha da Manhã, Recife. Reproduzido na revista Província de São Pedro, 1(2):172-173, set. 1945. 
${ }^{5}$ Neste quadro, "tanto mais [as entidades locais] não podem ser pensadas como conflitantes entre si, quanto mais mantenham trocas econômicas e demográficas desiguais" (Thiesse 1997:5).

${ }^{6}$ Carta a Manuel Bandeira, SP, 2/6/1928.

${ }^{7}$ Ao analisar os conteúdos trabalhados pelo Almanach Litterário de São Paulo, Antônio Celso Ferreira comenta que já nos vinte anos anteriores à proclamação da República, a elite política e intelectual paulista travava intensas discussões sobre a necessidade de conferir ao estado um papel político e cultural compatível com o surto progressista que acompanhou a expansão da lavoura cafeeira. Nesse contexto, "O progresso recente da província mal começara a ser assimilado no conjunto do país [...]. Os heróis paulistas ainda não figuravam nas narrativas históricas nacionalistas: eles viriam num futuro próximo, como resultado de uma construção textual que apenas se iniciava" (Ferreira 2002:44).

8 “Entre 1925 e 1926, os verde-amarelos rompem com os grupos Terra Roxa e Pau-Brasil. Desencadeia-se a partir de então uma verdadeira polêmica que tem como pano de fundo a questão da relação regionalismo-nacionalismo. Para os verde-amarelos, as demais correntes modernistas cometem um erro fundamental: encaram o regionalismo como motivo de vergonha e de atraso. Isto acontece, segundo seu ponto de vista, porque esses intelectuais teimam em ver o Brasil 'com olhos parisienses', o que leva, em decorrência, a que qualquer manifestação de brasilidade seja reduzida a regionalismo" (Velloso 1993:98).

${ }^{9}$ As particulares refrações do Modernismo no Rio Grande do Sul foram examinadas aprofundadamente por Lígia Chiapini de Moraes Leite. Analisando a prosa literária dos anos 20 e 30, a autora conclui que "os gaúchos receberam um Modernismo já diluído, o verde-amarelo, ao qual foram especialmente sensíveis porque lhes fornecia modelos para o canto apoteótico da terra e da raça". A mesma autora destaca que "o Modernismo foi responsável em grande parte por um clima propício à incrementação do Regionalismo e por uma releitura da tradição [na qual] contos tinham uma função de propagandear os valores gaúchos, como auxiliar na projeção política e econômica do Rio Grande, junto ao Poder Central" (Leite 1978:19-21). Sobre as tematizações do regionalismo paulista, ver Ferreira 2002 e Velloso 1993:123-ss.

${ }^{10}$ Houve pelo menos três tentativas anteriores à criação definitiva do IHGRS, em 1920. A primeira, em 1845, a segunda, em 1860 e uma terceira, em 1917. Referências a esses ensaios encontram-se às páginas 118, 119, 121, 122 e 123 do primeiro número da revista do Instituto, publicado em 1921. Os oradores chamados ao púlpito na sessão inaugural do IHGRS são unânimes em lamentar o atraso com que o Rio Grande, "possuindo elementos intelectuais em nada inferiores aos coirmãos", funda sua própria academia histórica, "atestado da cultura e do civismo dos povos" quando "em quase todos os Estados da república existiam sociedades, institutos, revistas histórico-geográficas, etc." (Revista IHGRS, n.1, p.119). Na ocasião da inauguração, o então tenente Souza Doca estende-se em considerações sobre as motivações e as responsabilidades dos sócios, "sobretudo agora, que se aproxima o primeiro centenário de nossa emancipação política", desejando "que o Rio Grande do Sul possa 
apresentar-se condignamente na magna data; que sejam por uma vez desfeitos os erros, as inverdades, as falsas apreciações que correm o mundo em livros de autores estrangeiros sobre o Rio Grande" (Revista IHGRS, n.1, p.120).

${ }^{11}$ Como marcaram Marlene Medaglia (1983) e Ieda Gutfreind (1989; 1995), os jovens e instruídos propagandistas da República foram os primeiros a manifestar uma linha de interpretação do passado que enfatizava o isolamento geográfico da região, a tardia ocupação do estado pela Coroa portuguesa, a insignificância de indígenas e negros para sua configuração étnica, o separatismo farroupilha, a proximidade física e cultural do Rio Grande com os países platinos (correspondente à presumida falta de afinidade com o Brasil), além da preeminência de um "regime democrático" de relações sociais entre patrões e empregados, "irmanados" pela vida rústica da campanha. Essa ênfase particularista permaneceria dominante na historiografia até o final da revolução de 1923, em consonância com o discurso político-ideológico perrepista. O patrulhamento a essas teses autonomistas inicia-se com a criação do IHGRS e se fortalece ao longo dos anos 30, quando os sócios do Instituto se aliam à cruzada política aliancista. A partir daí, os memorialistas trataram de legitimar documentalmente a oposição ingênita das duas variedades do gênero gaúcho - platina e brasileira — em teses que tomavam as relações entre o que viria a ser o Rio Grande do Sul e o Prata como a história da resistência dos brasileiros aos invasores espanhóis. A realização do Primeiro Congresso de História e Geografia Sul-rio-grandense como parte do calendário festivo do Centenário Farroupilha, em 1935, representa o momento de consolidação desta tendência enquanto evento aglutinador dos profissionais encarregados do reenquadramento da memória regional.

${ }^{12}$ Um dos efeitos mais imediatos do Modernismo sobre o cenário literário gaúcho foi a retomada dos autores fundadores do regionalismo. Em alguns casos, como a obra de Alcides Maya, essa retomada é crítica; em outros, como a de Simões Lopes Neto, que em 1926 inicia sua carreira póstuma, é entusiasmada. Em casos como o de Antônio Chimango, a popularidade vinha em uma linha de continuidade desde a publicação. Guilhermino César informa que a movimentação modernista rebenta exatamente no auge dessa popularidade (1994:51).

13 "A década de trinta assinala o decréscimo da participação do conto na literatura gaúcha, após dois decênios de uma produção significativa do gênero [...]. Com a ascensão do romance, o conto é relegado a um segundo plano, passando por uma fase intervalar de cerca de três décadas, caracterizada pela convivência do regionalismo com um incipiente conto urbano [...] enquanto o romance diferenciou-se a partir de 30, o conto persistiu na matriz regionalista tradicional até os anos cinqüenta" (Bittencourt 1999:31-32).

${ }^{14}$ Com a criação da Frente Única Gaúcha (FUG), em 1929. A frente era integrada pelos partidos Republicano Rio-grandense (PRR) e Libertador (PL), coligados para darem apoio à Candidatura de Vargas pela Aliança Liberal.

${ }_{15}$ Trata-se do tópico final do IV capítulo da obra A Província de São Pedro. Interpretação histórica do Rio Grande, publicada pela Editora Globo em 1930. O texto integra a antologia compilada por Chaves (1979:78-81). 
${ }^{16}$ Carta a Rui Cirne Lima, 25/6/28. Citada por Zilberman (1998), como epígrafe do livro Roteiro de uma literatura singular.

${ }^{17}$ Os dois renomados membros da Academia Brasileira de Letras denunciaram a penúria "positivóide" vivida por um estado passível de ser definido como "corpo estranho na Federação Brasileira", uma região economicamente "atrasadíssima", "lugar onde somente poderia vicejar um caudilho do estilo hispanoamericano (como Castilhos) - um ambiente de nômades 'semibárbaros'" (apud Love 1975:111). A mesma estranheza expressou Simão de Mântua (pseudônimo do jornalista João Lage), referindo-se, na Revista do Brasil, à fantástica "Comtelândia" do sul, ao sono profundo em que mergulhara ao término do primeiro parágrafo de um panfleto positivista (idem:112). Mais indiretamente essa crítica aparece em Alcântara Machado, que na "primeira dentição" da Revista de Antropofagia, em 1928, atribuiu "quase todas as tolices iniciais da República" aos "austeros namorados póstumos de dona Clotilde" (Machado 1976 [1928-1929]:s/p).

${ }^{18}$ Segundo Gilberto Freyre, o Manifesto Regionalista teria sido escrito em 1926 para ser apresentado no I Congresso Regionalista, realizado em Recife e promovido pelo Centro Regional, do qual o poeta regionalista Odilon Nestor viria a ser presidente. Publicado pela primeira vez em 1952 pela editora Região, em versão, como de hábito, retocada, e sem que Gilberto Freyre assumisse essa alteração, o manifesto causou estardalhaço na imprensa. Wilson Chagas desconfiou da afirmativa de Freyre, e Joaquim Inojosa, crítico do tradicional Jornal do Comercio (onde também Freyre e Nestor escreveram regularmente), acusou-o de fraude. No livro O Movimento Modernista em Pernambuco, publicado em 1968, enumera documentos comprobatórios de sua precedência, em relação a Freyre, na introdução e na divulgação do Modernismo no Recife. A versão aqui utilizada está disponível na internet: http://www. ufrgs.br/cdrom/freyre/comentario.html (consulta em março de 2004), sem paginação. As informações expostas acima constam do comentário de Antônio Dimas, que acompanha o texto na rede.

${ }^{19}$ As mais importantes coleções voltadas para revelar os aspectos marcantes da realidade nacional, nas décadas de 30, 40 e 50, foram A Brasiliana (criada em 1931 pela Companhia Editora Nacional e dirigida por Fernando de Azevedo), a Documentos Brasileiros (criada em 1936 pela José Olympio e dirigida, entre 19361939, por Gilberto Freyre; entre 1939-1959, por Otávio Tarquínio de Souza e, finalmente, a partir de 1962, por Afonso Arinos de Mello Franco) e a Biblioteca Histórica Nacional, editada pela Martins e criada pelo fundador José de Barros Martins, em 1940. Segundo Pontes, a diferença entre as duas primeiras coleções é "sobretudo regional, enquanto a primeira é mais ligada ao campo intelectual carioca e nordestino - que parece atribuir maior distinção ao exercício da literatura e da crítica a segunda acompanha mais de perto o movimento intelectual e cultural de São Paulo, o que explica [em razão do aparecimento da USP e à ascensão da sociologia como disciplina] o aumento do peso dos trabalhos sociológicos, estrito senso, ao longo de sua trajetória" (Pontes 1988:74). Nos anos 60, esse modelo das coleções já estava superado em favor de novos paradigmas explicativos; as análises sociológicas teriam primazia em relação à literatura e à produção ensaísta histórico-biográfica (Pontes 
1988:79). Sobre a concorrência da José Olympio com as outras editoras, ver Sorá, 1998. A posição da Globo nesse mercado também foi abordada na tese de Sorá, na segunda parte, intitulada "Gênesis de um pólo estrangeiro no espaço editorial".

${ }^{20}$ Of. 337, 28/6/54, de Dante de Laytano a José Honório Rodrigues. Museu Julio de Castilhos, Correspondência Expedida 1954, v.1, AP 1031.

${ }^{21}$ A observação teria sido feita, segundo Moysés Vellinho, por Afonso Arinos de Melo Franco, ao contrastar a literatura do norte com a do Rio Grande do Sul em Mar de sargaços. A resposta de Moysés Vellinho pode ser vista no editorial da revista Província de São Pedro 2(6):5-6, set. 1946, e em "Evocação de Afonso Arinos", conferência proferida no Conselho Federal de Cultura e publicada no Caderno de Sábado do Correio do Povo (P. Alegre, 9 nov. 1968). A questão da linguagem como marca de expressão própria a uma literatura brasileira seguia sendo, passadas quase três décadas do movimento modernista, um item primordial nas análises críticas de autores e obras. Neste sentido, Afonso Arinos chegou a ser comparado com Gilberto Freyre, "outro autor que também estuda o universal em função do nacional", e que, como Arinos, "jamais esquece sua carteira de identidade" (Correa 1948:48). A obra crítica de Afonso Arinos consta dos livros Espelho de três faces (1937); Idéia e tempo (1939); Mar de sargaços (1944); Portulano (1945), e O som do outro sino (1978).

${ }^{22}$ Desde o primeiro lançamento de Prosa dos pagos, em 1943, mas sobretudo a partir da década seguinte, com os estudos Guia do folclore gaúcho e cancioneiro gaúcho, respectivamente lançados em 1951 e 1952, Meyer acumula às consabidas qualidades de crítico e poeta, a autoridade do pesquisador social, preterindo a poesia em prol de novas intenções que exploram o potencial documental da atividade literária, em especial da literatura regionalista.

${ }^{23}$ Martins, Cyro. "Introdução". In: Sem rumo (romance). 6.ed. 1997. Porto Alegre: Movimento. p.14-ss. (1.ed., 1937). Ensaio originalmente publicado em 1944. A versão aqui utilizada encontra-se disponível na internet, sem dispor da paginação original. Ver http://www.celpcyro.org.br/coluna_int.asp? codigo=24. Acesso em 21 de novembro de 2002.

${ }^{24}$ Idem.

${ }^{25}$ A aula foi enviada ao "mestre" um ano mais tarde: "As notícias do ilustre amigo cessaram misteriosamente e não tive nunca mais nem ao menos um cartão de tantas dessas suas viagens. Mando-lhe uma aula inaugural feita ano passado, na qual lhe cito várias vezes [...] e entrei em diversas liberdades. Uma tentativa de estudar um dos aspectos de sua bela obra, pedindo que me desculpe a intromissão, mas nos meus cursos o exame de seus livros é um elogio obrigatório". Carta de Dante de Laytano a Gilberto Freyre, 31/03/54. Museu Julio de Castilhos, Correspondência Expedida, v1-1954, AP 1031.

${ }^{26}$ Estas eram entendidas à época como um domínio temático preferencial da "sociologia", enquanto as "influências" étnicas subjacentes a tais manifestações per- 
maneciam, para efeitos classificatórios, a cargo da "antropologia". Com base nessa divisão, Dante de Laytano ressalvou as naturezas diferentes das ascendências de Gilberto Freyre e Arthur Ramos sobre sua obra, no tópico "Antropologia do negro Arthur Ramos", de suas memórias "dos outros", como ele mesmo chamara: "[Artur Ramos] representou, para mim, uma amizade sólida, além de ser ele uma de minhas influências decisivas no inclinar-me na pesquisa do homem de cor. [...] Dediquei a Arthur Ramos meu trabalho sobre 'Os africanismos do dialeto gaúcho' que teve crítica lindíssima. Este livro é em homenagem devota a minha filiação a linha espiritual de Arthur Ramos. Quanto a Gilberto Freyre minha fidelidade é de caráter sociológico. Diria que com Arthur Ramos fixa-se no caso antropológico" (Laytano 1986:89).

${ }^{27}$ Além de abordar a questão a partir do aspecto filológico — nos artigos compilados em O linguajar do gaúcho brasileiro (1981) - e folclórico - em Folclore do Rio Grande do Sul (1987), este também uma recompilação revisada dos trabalhos apresentados em congressos de História e Folclore — nas memórias de 1986 são muitas as passagens dedicadas ao tema. Nelas, o autor não deixa de confirmar a tese da escassez demográfica da população negra, mas contrapõe a ela sua relevância cultural, confirmada pela presença nas expressões de religiosidade popular, na linguagem e nos costumes (Laytano 1986:89).

${ }^{28}$ Contrariamente aos ditames historiográficos segundo os quais o regime de trabalho escravo no Rio Grande ter-se-ia limitado à indústria do charque, a narrativa construída pelo autor destaca: "Com a escravidão, muito estancieiro chegaria mesmo a dispensar o assalariado. Comprava os quinze ou vinte anos que podia dar-lhe o trabalho de um negro escravo por quantia correspondente à quadragésima parte do total empenhado em pagamento de um peão, no mesmo período. O peão pobre, o proletário rural, aprendia portanto bem cedo esta dura experiência: de nada lhe servia a aptidão para o trabalho" (Meyer 2002 [1960]:26).

${ }^{29}$ Segundo Guilhermino César, a crítica local imediatamente identificou na novela uma metáfora urbana da lenda do Negrinho do pastoreio (César 1994:139-140).

${ }^{30} \mathrm{O}$ trabalho, publicado com fotos ilustrativas, foi republicado no livro Problemas brasileiros de antropologia, editado pela Casa do Estudante do Brasil, em 1943. Em 1946, foi incluído na revista Província de São Pedro, 2(7):10-15. Também se encontra disponível na web:http://prossiga.bvgf.fgf.org.br/portugues/obra/opusculos/sugestoes_estudos.htm. Já o estudo de Athos Damasceno Ferreira, intitulado "Sacadas e sacadinhas porto-alegrenses", saiu na Província de São Pedro, 1(2): 63-76, Porto Alegre, set. 1945. Acompanham-no ilustrações em bico de pena feitas pelo próprio autor, que também era desenhista de ocasião. 


\section{Referências bibliográficas}

ANDERSON, Benedict. 1989. Nação e consciência nacional. São Paulo: Ática.

ALBUQUERQUE Jr., Durval Muniz de. 2001. A invenção do Nordeste e outras artes. Recife: FJN/ Ed. Massangana; São Paulo: Cortez.

ALMEIDA, Marlene Medaglia. 1983. Introdução ao estudo da historiografia sul-rio-grandense: inovações e recorrências do discurso oficial (1920-1935). Dissertação de mestrado em sociologia, IFCH/UFGRS.

ARAÚJO, Ricardo Benzaquém de. 1994. Guerra e paz: casa-grande e senzala e a obra de Gilberto Freyre nos anos 30. Rio de Janeiro: Ed. 34.

BERTASO, José Otávio. 1993. A globo da rua da praia. São Paulo: Globo.

BITTENCOURT, Gilda Neves da Silva. 1999. O conto sul-rio-grandense. Tradição e modernidade. Porto Alegre: EdUFRGS.

BOEIRA, Nelson. 1980. "O Rio Grande de Augusto Comte". In: J. I. Dacanal \& S. Gonzaga (orgs.), RS: cultura e ideologia. Porto Alegre: Mercado Aberto. pp.34-59.

BOURDIEU, Pierre. 1989. "A identidade e a representação. Elementos para uma reflexão crítica sobre a idéia de região". In: O poder simbólico. Lisboa: Difel. pp.107-132.

CÉSAR, Guilhermino. 1994. Notícia do Rio Grande. Porto Alegre: IEL/ EdUFRGS.

CHAVES, Celso Loureiro. 1979. O ensaio literário no Rio Grande do Sul (18681960). Brasília: INL.

CORREA, Nereu. 1948. "Poesia e crítica". Província de São Pedro, 4(12):48-52.

CUNHA, Euclides da. 1995 [1902]. Os Sertões. Campanha de Canudos. Rio de Janeiro: Francisco Alves.
FERREIRA, Antônio Celso. 2002. A epopéia bandeirante: letrados, instituições, invenção histórica (1870-1940). São Paulo: EdUnesp.

FERREIRA, Atos D. 1945. "Sacadas e sacadinhas porto-alegrenses". Província de São Pedro, 1(2):63-76. . 1954. "Trunfas, Caipis e Tipóis. Contribuição para o estudo da indumentária no Rio Grande do Sul". Província de São Pedro, 10(20):93104.

FREYRE, Gilberto. 1940a. "Sugestões para o estudo histórico-social do sobrado no Rio Grande do Sul". IHGRS, Anais do III Congresso SulRiograndense de História e Geografia. Porto Alegre: Livraria do Globo. pp. XIII-XX. 1940b. "Narcisismo gaúcho". Revista do Globo, 274:14-15. . 1943. Continente e ilha. Rio de Janeiro: CEB. . 1992 [1933]. Casa Grande e Senzala. Introdução à história da sociedade patriarcal no Brasil. Rio de Janeiro: Record.

FISCHER, Luís Augusto. 2002. "Augusto Meyer, um ensaísta da Comarca do Pampa". Conferência proferida na Academia Brasileira de Letras, como parte do ciclo de conferências comemorativo ao centenário de nascimento do acadêmico. Disponível na Internet em < http://academia.insite. com.br/2002/pales40.htm > . Consultado em agosto de 2004.

GARCIA JR. Afrânio. 1993. "Les intellectuels et la conscience nactionale au Brésil". Actes de la Recherche en Sciences Sociales, 98:20-33.

GUTFREIND, Ieda. 1989. A construção de uma identidade: a historiografia 
sul-rio-grandense de 1925 a 1975. Tese de doutorado em história, IFCH/USP.

1995. "A historiografia sulrio-grandense e o mito do gaúcho brasileiro". In: S. Gonzaga \& L. A. FIicher (orgs.), Nós, os gaúchos. Porto Alegre: EdUFRGS. pp.148-152.

IHGRS. 1940. "Discurso do Dr. Manoel Duarte". Anais do III Congresso Sul-rio-grandense de História e Geografia. Porto Alegre: Prefeitura Municipal de Porto Alegre. pp. CCCXXI-CCCXXX

1921. "Atas das sessões do Instituto Histórico e Geográfico do Rio Grande do Sul". Revista do Instituto Histórico e Geográfico do Rio Grande do Sul, 1:107-134.

LAYTANO, Dante de. 1950. "Corridas de boi no Rio Grande do Sul". Correio do Povo, Porto Alegre, 24 agosto 1950, p. 7.

1953. "A História e suas re-

lações com algumas ciências. Aula Inaugural proferida na abertura dos cursos da Faculdade de Filosofia da Universidade do Rio Grande, em 1953". Aulas inaugurais dos cursos da Faculdade de Filosofia da Universidade do Rio Grande do Sul. Porto Alegre: URGS. pp. 3-27.

"A Igreja e os orixás". Publicações da Comissão Estadual de Folclore do Rio Grande do Sul /CNFL/ IBECC, n. 29, Rio de Janeiro, s/d. 1981. O linguajar do gaúcho brasileiro. Porto Alegre: Escola Superior de Teologia São Lourenço de Brindes.

1983. História da república rio-grandense (1835-1845). Porto Alegre: Sulina.

1986. Mar absoluto das memórias. Porto Alegre: Martins Livreiro. 1987. Folclore do Rio Grande do Sul: levantamento dos costumes e tradições gaúchas. Caxias do Sul: EDUCS.

1998. Entrevista concedida à autora. Porto Alegre, 30 de setembro de 1998. Gravação em fita cassete.

LEITE, Lígia Chiappini Morais. 1978. Regionalismo e modernismo (o "Caso" gaúcho). São Paulo: Ática.

LINS DO REGO, José. 1941. "Notas sobre Gilberto Freyre". In: Região e tradição. Rio de Janeiro: José Olympio (Coleção Documentos Brasileiros). pp. 9-21.

LOVE, Joseph L. 1975. O regionalismo gaúcho e as origens da Revolução de 1930. São Paulo: Perspectiva.

MACHADO, Antônio A. 1976 [19281929]. "Carniça". Revista de Antropofagia. São Paulo, [s.n.], ano I-II, 1928-1929. Fac-símile. São Paulo: Metal Leve, s/p.

MEYER, Augusto. 2002 [1960]. Prosa dos pagos (1941-1959). Porto Alegre: IEL/CORAG.

MICELI, Sérgio. 1979. Intelectuais e classe dirigente no Brasil (1920-1945). Rio de Janeiro: Difel.

MOOG, Gilberto V. 1983. "Depoimento. Painel Escritores e Jornalistas". Anais do Simpósio sobre a Revolução de 30. Porto Alegre: ERUS. pp. 614-618.

MORAES, Marcos A. [org.]. 2000. Correspondência. Mário de Andrade \& Manuel Bandeira. São Paulo: Edusp.

NEDEL, Letícia Borges. 1999. Paisagens da província: o regionalismo sul-rio-grandense e o Museu Julio de Castilhos nos anos cinqüenta. Dissertação de mestrado em história, PPGH/UFRJ.

2005. Um passado novo para uma história em crise: regionalismo e folcloristas no Rio Grande do Sul (1948-1965). Tese de doutorado em história, PPGH/UnB.

OLIVEN, Ruben George. 1992. A parte e o todo: a diversidade cultural no Brasil-Nação. Petrópolis: Vozes. 
PINTO, Céli Regina J. 1986. Positivismo: um projeto político alternativo ( $R S$ : 1889-1930). Porto Alegre: LP\&M.

PONTES, Heloísa. 1988. "Retratos do Brasil: um estudo dos editores, das editoras e das 'Coleções Brasilianas' nas décadas de 1930, 40 e 50". BIB(26):56-90.

SEYFERTH, Giralda. 2000. "O regionalismo da tradição na perspectiva nacionalista: a identidade regional segundo Gilberto Freyre". Anais do Seminário Internacional Novo Mundo nos Trópicos. Recife: Fundação Gilberto Freyre. pp.180-193.

SORÁ, Gustavo. 1998. Brasilianas. A casa José Olympio e a instituição do livro nacional. Tese de doutorado em antropologia, PPGAS/ UFRJ.

THIESSE, Anne-Marie. 1999. La creation des identités nationales. Paris: Seuil. 1997. Ils apprenaient la France. L'exaltation des régions dans le discours patriotique. Paris: Maison des Sciences de l'Homme.

TORRES, Luiz Henrique. 1997. Historiografia sul-rio-grandense: o lugar das missões jesuítico-guaranis na formação histórica do Rio Grande do Sul (1819-1975). Tese de doutorado em História do Brasil, Pontifícia Universidade do Rio Grande do Sul.

VELLINHO, Moysés. 1946. "Editorial". Província de São Pedro, 2(6):5-6. . 1948. "Editorial". Província de São Pedro, 4(11):5-7. . 1957. "O balanço crítico da literatura rio-grandense". Província de São Pedro, 11(21):221-225.

VELLOSO, Mônica P. 1993. "A brasilidade verde-amarela: nacionalismo e regionalismo paulista". Estudos Históricos, 6(11):89-112.

VERISSIMO, Érico. 1973. Um certo Henrique Bertaso. Porto Alegre: Editora Globo.

VILHENA, Luís Rodolfo. 1997. Projeto e missão: o Movimento Folclórico Brasileiro (1947-1964). Rio de Janeiro: FUNARTE/ FGV.

ZILBERMAN, Regina. 1998. Roteiro de uma literatura singular. Porto Alegre: EdUFRGS. 


\section{Resumo}

É no contexto do pós-Estado Novo, quando o revisionismo toma conta da produção historiográfica sul-rio-grandense, que os escritos de Gilberto Freyre obtêm maior repercussão entre a intelectualidade sulina. O artigo detém-se sobre as motivações desse alinhamento tardio com as opções analíticas do autor recifense. Em um momento marcado pela ascensão das ciências sociais e pela perda de autoridade das narrativas históricas até então centradas no papel integrador dos heróis militares, historiadores e críticos locais atuam conjuntamente em favor da reversão dos motivos que apartavam a produção textual da "província" dos temas em voga no centro do país. Nesse passo, fez-se mister a aproximação da História com o Folclore, este apreendido não mais como um ramo da filologia ou do regionalismo literário, mas sob um viés "sociológico".

Palavras-chave: Pensamento Social Brasileiro, Rio Grande do Sul, Folclore, Historiografia, Regionalismo

\section{Abstract}

The period in the wake of the Novo Estado (New State), when revisionism took hold of historiographic production in Rio Grande do Sul, provided the context for the writings of Gilberto Freyre to acquire a greater influence among the southern intelligentsia. The article investigates the reasons for this delayed alignment with the analytic model of the Recife author. At a time marked by the rise of the social sciences and the loss in authority of historical narratives centred on the integrating role of military heroes, local historians and critics combined forces to reverse the motivating factors that had previously separated the textual production of the 'province' from the themes in fashion in the intellectual 'centre' of Brazil (Rio de Janeiro and São Paulo). This step required closing the gap between History and Folklore, meaning the latter was no longer apprehended as a branch of philology or literary regionalism, but as an area of study to be approached from a 'sociological' angle.

Key words: Brazilian Social Thought, Rio Grande do Sul, Folklore, Historiography, Regionalism 